\title{
PERANAN JAMINAN SOSIAL TENAGA KERJA DALAM PERWUJUDAN CITA PEMBANGUNAN HUKUM TENAGA KERJA DI INDONESIA
}

\author{
Anik Iftitah, \\ Mahasiswa Fakultas Hukum Universitas Islam Balitar, Blitar, \\ E-mail : geest_willdaad@yahoo.com; HP. 085646498763.
}

\begin{abstract}
ABSTRAKSI
Tenaga kerja merupakan salah satu pelaku utama pembangunan untuk meningkatkan produktifitas nasional dan kesejahteraan masyarakat Indonesia. Namun kemampuan bekerja dan penghasilan tenaga kerja dapat berkurang atau hilang karena berbagai resiko seperti sakit, kecelakaan, cacat, hari tua atau meninggal dunia. Oleh karenanya, pemerintah memberlakukan Undang-Undang Nomor 3 Tahun 1992 tentang Jaminan Sosial Tenaga Kerja yang memberikan perlindungan bagi tenaga kerja. Persoalannya kemudian adalah apa peran pelaksanaan program jaminan sosial tenaga kerja dalam pembangunan manusia Indonesia seutuhnya dan pembangunan masyarakat Indonesia seluruhnya sebagai cita pembangunan hukum ketenagakerjaan di Indonesia. Penelitian yuridis normatif peranan jaminan sosial tenaga kerja dalam perwujudan cita pembangunan hukum tenaga kerja di Indonesia menunjukkan bahwa peran jaminan sosial tenaga kerja dalam perwujudan cita pembangunan hukum ketenagakerjaan di Indonesia adalah sebagai manifestasi kepastian hukum guna menciptakan keseimbangan hubungan kerja yang mewujudkan keadilan, sebagai perwujudan penerapan nilai-nilai hukum (law in action) dan sebagai satu teknik dalam perwujudan cita hukum ketenagakerjaan di Indonesia.
\end{abstract}

Kata kunci: Jaminan Sosial, Pembangunan Hukum, Tenaga Kerja

\section{PENDAHULUAN}

Sejarah kehidupan kemerdekaan Indonesia telah terbuka lebar sejak 17 Agustus 1945. Dimensi kemerdekaanya, semestinya melingkupi segala lini kehidupan masyarakatnya. Namun, salah satu aspek penunjang kehidupan dan pembangunan di Indonesia, yaitu masalah kegiatan ketenagakerjaan, masih terus menerus menjadi salah satu problema yang berkepanjangan. Sebagai satu contoh, pada periode tahun 2001-2004 tercacat bahwa pertambahan angkatan kerja baru sebesar 1,72 juta per tahun, dengan kesempatan kerja yang mampu tercipta 970 ribu per tahun. Pada periode 2005-2009, angkatan kerja bertambah 1,99 juta per tahun sementara kesempatan kerja yang tercipta sebesar 2,73 juta per tahun. Dengan demikian, nampak jelas bahwa jumlah penganggur dapat diturunkan dari 10,25 juta tahun 2004 menjadi 8,96 juta tahun 2009, dan tingkat pengangguran terbuka menurun dari 9,86\% menjadi 7,87\%. Namun, kesempatan kerja tetap tercipta tetapi pemutusan hubungan kerja (PHK) yang dimulai sejak akhir tahun 2008 tetap terjadi. Jumlah perusahaan yang mengajukan permohonan PHK-pun cukup banyak seiring dengan berakhirnya kontrak. ${ }^{1}$

Hal tersebut di atas dapat dengan mudah dipahami mengingat kehidupan manusia sebagai kegiatan adalah bola permainan ${ }^{2}$ dari empat faktor pokok ${ }^{3}$ dalam kehidupan sosial

\footnotetext{
1 Kondisi Umum dalam Dokumen Rencana Pembangunan Jangka Menengah Nasional (RPJMN) 2010-2014. Penjabaran visi, misi dan program aksi pembangunan nasional Presiden / Wakil Presiden Susilo Bambang Yudhoyono - Boediono. www.ditpertais.net. Diakses pada 1 Juni 2010.

2 Al Quran Surat Muhammad Ayat 36, "Sesungguhnya kehidupan dunia itu hanyalah permainan dan senda gurau. Jika kamu beriman serta bertakwa, Allah akan memberikan pahala kepadamu, dan Dia tidak akan meminta hartamu". Departemen Agama RI. Al-Quran dan Terjemahannya, Surabaya : Mekar Surabaya, 2004.
} 
manusia. Dimana jika semata-mata menurutkan pada faktor kehidupannya saja, manusia dengan kegiatannya akan menjurus kearah kekacaubalauan dengan wujud kehidupannya yang exploitation the lhome par lhome, 4 penjajahan/pemerasan oleh manusia atas dan terhadap manusia lainnya. Suatu kenyataan yang jelas dan pasti bertentangn dengan dasar negara Indonesia, yaitu Pancasila. ${ }^{5}$

Mengingat dan menimbang hal tersebut di atas, Negara Indonesia sebagai negara hukum (rechsstaat) ${ }^{6}$ dan bukan negara yang berdasarkan kekuasaan belaka (Machsstaat), dengan konstitusinya yaitu Undang-Undang Dasar (UUD) 1945 berkewajiban menjamin kesejahteraan tiap-tiap warga negaranya, tidak terkecuali dalam bidang ketenagakerjaan guna mewujudkan hubungan ketenagakerjaan ${ }^{7}$ yang adil ${ }^{8}$ tanpa adanya exploitation antar pihak terkait.

Pemerintah sebagai stabilisator dan dinamisator di bidang ketenagakerjaan, berdasar UUD 1945 Pasal 27 ayat 2 (dua) ${ }^{9}$ selanjutnya bertindak mengeluarkan peraturan-peraturan yang mengatur sejak seseorang mulai mencari pekerjaan sampai timbulnya masalah hubungan kerja dan berakhirnya hubungan kerja, untuk memberikan perlindungan dan kesempatan pada pihak dalam hubungan kerja. Dengan lain perkataan, pemerintah Indonesia bertanggungjawab melaksanakan kebijaksanaan kenegaraan di bidang pembuatan hukum ketenagakerjaan dengan pola menyeimbangkan kepentingankepentingan pihak dalam hubungan ketenagakerjaan sesuai dengan perkembangan zaman, yang jelas tidak akan terlepas dari perubahan dan pertumbuhan yang jikalau tidak secara responsif, represif dan preventif terus-menerus diperhatikan, akan mewujudkan suatu kehidupan yang penuh kekacaubalauan, yang praktis bertentangan dengan cita hukum sebagai tatanan kehidupan.

\footnotetext{
${ }^{3}$ Terjemahan bebas Al Quran Surat Ali Imran, Ayat 14. "Manusia ialah makhluk yang mempunyai kecenderungan hawa nafsu terhadap wanita, anak, kekayaan berupa emas dan perak, kuda yang bagus binatang-binatang dan tumbuh-tumbuhan, untuk hiasan dunia". Ibid.

${ }^{4}$ Kamus Asing dalam Soekarno, Doktrin Revolusi Indonesia, Surabaya : CV. Narsih, 1962.

${ }^{5}$ Pembukaan (Preambule) Undang-Undang Dasar (UUD) 1945 alinea pertama, "Bahwa sesungguhnya Kemerdekan itu ialah hak segala bangsa dan oleh sebab itu, maka penjajahan di atas dunia harus dihapuskan, karena tidak sesuai dengan perikemanusiaan dan perkeadilan".

6 Pasal 1 ayat 3 UUD 1945 amandemen ke-empat yang dipertegas kembali dalam Penjelasan Umum tentang Sistem Pemerintahan Negara.

7 Pihak-pihak yang terlibat sebagai penyelenggara hubungan ketenagakerjaan di dalam hubungan ketenagakerjaan antara lain perusahaan atau majikan dan tenaga kerja atau buruh. Seperti yang kita ketahui bersama bahwa pengertian tenaga kerja menurut UU No. 13/2003 tentang Ketenagakerjaan pasal 1 angka 3 adalah setiap orang yang bekerja dengan menerima upah atau imbalan dalam bentuk lain; sedangkan perusahaan menurut UU No. 13/2003 angka 6 ialah setiap bentuk usaha yang berbadan hukum atau tidak, milik orang perseorangan, milik persekutuan, atau milik badan hukum, baik milik swasta maupun milik negara yang mempekerjakan tenaga kerja atau buruh dengan membayar upah atau imbalan dalam bentuk lain; atau usaha-usaha sosial dan usaha-usaha lain yang mempunyai pengurus dan mempekerjakan orang lain dengan membayar upah atau imbalan dalam bentuk lain. Perhatikan pula UUD 1945 amandemen ke-empat Pasal 28D ayat 2, "Setiap orang berhak untuk bekerja serta mendapat imbalan dan perlakuan yang adil dan layak dalam hubungan kerja".

8 Adil berdasarkan kaidah Ushul Fiqhi ialah "at-tawassuthu bainal amraini" (berdiri di tengah-tengah antara dua perkara), mirip dengan teori "evenredigheids postulat" (asas keseimbangan) dari Prof. Kranenburg dan senafas dengan teori keadilan Aristoteles, "memberi kepada tiap-tiap orang apa yang berhal ia terima". (Dari : Prof. Dr. Baharuddin Lopa, S.H.. Permasalahan Pembinaan dan Penegakan Hukum di Indonesia, Jakarta : Bulan Bintang, h.126), 1987

9 "Setiap warga negara berhak atas pekerjaan dan kehidupan yang layak".
} 
Selaras dengan cita tersebut di atas, maka negara melalui pemerintah sebagai lembaga eksekutifnya terus-menerus tiada henti melakukan pembangunan hukum ketenagakerjaan sesuai dengan peraturan perundang-undangan, memenuhi salah satu ciri atau unsur dari negara hukum sebagaimana yang dikemukakan oleh Prof. DR. Sudargo Gautama, SH. yaitu azas legalitas ${ }^{10}$, yang menurut Lon L. Fuller ${ }^{11}$ harus memenuhi dan mewujudkan 8 (delapan) nilai-nilai sebagai 8 (delapan) prinsip legalitas yaitu : 1). harus ada peraturan-peraturan terlebih dahulu, tidak ada tempat bagi keputusan-keputusan secara ad-hoc, atau tindakantindakan yang bersifat arbitrer; 2). peraturan-peraturan itu harus diumumkan secara layak; 3). peraturan-peraturan itu tidak boleh berlaku surut; 4). perumusan peraturan-peraturan itu harus jelas dan terperinci, harus dapat dimengerti oleh rakyat; 5). hukum itu tidak boleh meminta dijalankan hal-hal yang impossible; 6). diantara sesama peraturan tidak boleh terdapat pertentangan satu sama lain; 7). peraturan-peraturan harus tetap, tidak boleh sering di ubah-ubah; dan 8).harus terdapat kesesuaian antara tindakan-tindakan para pejabat hukum dan peraturan-peraturan yang telah dibuat.

Peraturan perundang-undangan yang memuat mengenai pembangunan hukum ketenagakerjaan khususnya termuat dalam Undang-Undang No. 13 Tahun 2003 tentang Ketenagakerjaan. Berdasarkan ketentuan pasal 2 UU Ketenagakerjaan tersebut, pembangunan ketenagakerjaan dilaksanakan berlandaskan Pancasila dan Undang-Undang Dasar Republik Indonesia Tahun 1945 dalam rangka pembangunan manusia Indonesia seutuhnya untuk mewujudkan manusia dan masyarakat Indonesia yang sejahtera, adil, makmur dan merata baik materiil maupun spiritual, dengan asas yang disesuaikan dengan asas pembangunan nasional khususnya asas demokrasi Pancasila serta asas adil dan merata, dengan tujuan a. memberdayakan dan mendayagunakan tenaga kerja secara optimal dan manusiawi; b. mewujudkan pemerataan kesempatan kerja dan penyediaan tenaga kerja yang sesuai dengan kebutuhan pembangunan nasional dan daerah; c. memberikan perlindungan kepada tenaga kerja dalam mewujudkan kesejahteraan dan; d. meningkatkan kesejahteraan tenaga kerja dan keluarganya ${ }^{12}$.

Penekanan pembangunan hukum ketenagakerjaan pada tenaga kerjanya seperti yang tertulis di atas sangat lazim mengingat tenaga kerja merupakan pelaku pembangunan. Berhasil tidaknya pembangunan terletak pada kemampuan dan kualitas para tenaga kerjanya. Tenaga kerja menduduki posisi yang strategis untuk meningkatkan produktifitas

10 Prof. DR. Sudargo Gautama, SH. mengemukakan 3 ciri-ciri atau unsur-unsur dari negara hukum, yakni :

a. Terdapat pembatasan kekuasaan negara terhadap perorangan, maksudnya negara tidak dapat bertindak sewenang-wenang. Tindakan negara dibatasi oleh hukum, individual mempunyai hak terhadap negara atau rakyat mempunyai hak terhadap penguasa.

b. Azas Legalitas

Setiap tindakan negara harus berdasarkan hukum yang telah diadakan terlebih dahulu yang harus ditaati juga oleh pemerintah atau aparaturnya.

c. Pemisahan Kekuasaan

Agar hak-hak azasi itu betul-betul terlindung adalah dengan pemisahan kekuasaan yaitu badan yang membuat peraturan perundang-undangan, melaksanakan dan mengadili harus terpisah satu sama lain tidak berada dalam satu tangan.

S. Anwary. Makalah Penegakan Negara Hukum di Republik Indonesia. Blog.unila.ac.id/pdih/.../temadan-topik-seminar-hukum-nasional.pdf. Diakses pada Juni 2010.

11 Satjipto Rahardjo SH, Hukum dan Masyarakat, Bandung : Angkasa, 1981.

12 Pasal 4 UU No. 13 Tahun 2003 tentang Ketenagakerjaan. 
nasional dan kesejahteraan masyarakat. Apabila kemampuan tenaga kerja tinggi maka produktifitas akan tinggi pula, yang dapat mengakibatkan kesejahteraan meningkat. Tidak bisa dipungkiri bahwa peran serta tenaga kerja semakin meningkat. Namun kemampuan bekerja dan penghasilan tenaga kerja dapat berkurang atau hilang karena berbagai resiko seperti sakit, kecelakaan, cacat, hari tua atau meninggal dunia. Dan seiring dengan itu perlindungan tenaga kerja harus semakin ditingkatkan. Oleh karenanya, pemerintah sebagai lembaga eksekutif guna mewujudkan cita pembangunan hokum ketenagakerjaan di Indonesia, menerapkan dan memberlakukan Undang-Undang Nomor 3 Tahun 1992 tentang Jaminan Sosial Tenaga Kerja (Jamsostek) yang mengatur dalam kepesertaan dan mekanisme pemberian jaminan yang memberikan perlindungan sehingga tercipta rasa aman dan nyaman bagi tenaga kerja, dengan ruang lingkup Program Jamsostek meliputi 4 macam, yaitu : a. Jaminan Kecelakaan Kerja (JKK); b. Jaminan Kematian (JKM); c. Jaminan Hari Tua (JHT); dan d. Jaminan Pemeliharaan Kesehatan (JPK); bagi seluruh tenaga kerja dan keluarganya.

\section{METODE PENELITIAN}

Penelitian dengan pendekatan hukum normatif ${ }^{13}$ ini dilakukan dengan studi literatur, dokumentasi peraturan perundang-undangan, kebijakan, teori-teori, dan asas-asas yang berkaitan dengan Jaminan Sosial Tenaga Kerja (Jamsostek) dan pembangunan hukum ketenagakerjaan. Penelitian ini merupakan penelitian deskriptif tanpa bermaksud untuk menguji hipotesa atau teori, tetapi merupakan kegiatan menganalisis dan mengklasifikasikan atau mensistematisasi bahan-bahan hukum.

Dalam penulisan ini data yang peneliti pergunakan adalah data sekunder yang terdiri dari ${ }^{14}$ :

a. Bahan hukum primer, yaitu bahan-bahan hukum yang mengikat berupa peraturan perundang-undangan yang berhubungan dengan masalah penelitian yaitu:

1. Undang-Undang Dasar 1945 amandemen ke-IV;

2. Undang-Undang No. 3 Tahun 1992 tentang Jaminan Sosial bagi Tenaga Kerja;

3. Undang-Undang No. 13 Tahun 2003 tentang Ketenagakerjaan; dan

4. Peraturan perundang-undangan lain yang terkait seperti Peraturan Pemerintah (PP) No. 14 Tahun 1993 tentang Penyelenggaraan Jaminan Sosial Tenaga Kerja, dan lainlain.

b. Bahan hukum sekunder, yaitu data yang diperoleh melalui bahan pustaka maupun dari dokumen berupa bahan hukum. Data ini penulis peroleh dari:

1) Sumber hukum syariah yang berkaitan dengan masalah yang dibahas.

2) Berbagai buku yang berkaitan dengan masalah yang dibahas.

3) Hasil penelitian yang berkaitan dengan masalah yang dibahas.

c. Bahan hukum tersier, yaitu bahan yang memberikan petunjuk maupun penjelasan terhadap bahan hukum primer dan sekunder, seperti Kamus Asing, Kamus Besar Bahasa Indonesia (KBBI) dan lain-lain.

\footnotetext{
13 Bambang Sunggono, Metodologi Penelitian Hukum, Jakarta : PT Raja Grafindo Persada, 2005, h.41.

${ }^{14}$ Adi Rianto, Metodologi Penelitian Sosial \& Hukum, Jakarta : Granit, 2004, h.57.
} 
Peneliti melakukan studi kepustakaan baik itu melalui literatur yang penulis miliki sendiri maupun dari literatur yang telah tersedia di perpustakaan ${ }^{15}$, selanjutnya dilakukan pemeriksaan dan pengkajian lebih dalam untuk menjamin ketepatan dan dapat dipertanggungjawabkan sesuai peraturan, teori dan konsep. Cara analisa data yang digunakan adalah analisa deskriptif kualitatif yaitu analisa terhadap data yang tidak bisa dihitung ${ }^{16}$. Data yang diperoleh selanjutnya dilakukan pembahasan, pemeriksaan dan pengelompokan ke dalam bagian-bagian tertentu untuk diolah menjadi data informasi. Hasil analisa bahan hukum akan diinterpretasikan untuk menjawab persoalan dalam rumusan masalah ${ }^{17}$ dan diharapkan dapat memperluas wawasan khususnya terkait hukum ketenagakerjaan.

\section{GAMBARAN PELAKSANAAN JAMINAN SOSIAL TENAGA KERJA DI INDONESIA}

Jaminan sosial tenaga kerja (Jamsostek) adalah suatu perlindungan bagi tenaga kerja dalam bentuk bantuan berupa uang sebagai pengganti sebagian dan penghasilan yang hilang atau berkurang dan pelayanan sebagai akibat peristiwa atau keadaan yang dialami oleh tenaga kerja berupa kecelakaan kerja, sakit, hamil, bersalin, hari tua dan meninggal dunia ${ }^{18}$, yang diwajibkan bagi tiap-tiap perusahaan sebagaimana yang tersurat dalam pasal 1 angka 6 UU No. 13 Tahun 2003 tentang Ketenagakerjaan yaitu setiap bentuk usaha yang berbadan hukum atau tidak, milik orang perseorangan, milik persekutuan, atau milik badan hukum, baik milik swasta maupun milik negara yang mempekerjakan pekerja/buruh dengan membayar upah atau imbalan dalam bentuk lain, usaha-usaha sosial dan usahausaha lain yang mempunyai pengurus dan mempekerjakan orang lain dengan membayar upah atau imbalan dalam bentuk lain.

Kewajiban mengikutsertakan tenaga kerjanya dalam program Jamsostek bagi setiap perusahaan tersebut khusus mengikat dalam batasan ketentuan bahwa hanya pengusaha yang mempekerjakan tenaga kerja sebanyak 10 (sepuluh) orang atau lebih, atau membayar upah paling sedikit Rp 1.000.000,- (satu juta rupiah) orang atau lebih, atau membayar upah paling sedikit Rp 1.000.000,- (satu juta rupiah) pengusaha yang mempekerjakan tenaga kerja sebanyak 10 (sepuluh) orang atau lebih, atau membayar upah paling sedikit Rp 1.000.000,(satu juta rupiah) sebulan. ${ }^{19}$

Dengan lain perkataan, maka setiap perusahaan di Indonesia yang memenuhi ketentuan seperti tersebut di atas berkewajiban untuk memberikan Jaminan Sosial Tenaga Kerja (Jamsostek) sebagai hak bagi setiap tenaga kerjanya tanpa terkecuali dan tanpa paksaan macam apapun. ${ }^{20}$

\footnotetext{
15 Ibid.

16 Pendekatan kualitatif memusatkan perhatiannya pada prinsip-prinsip umum yang mendasari perwujudan satuan-satuan gejala yang ada dalam kehidupan manusia, atau pola-pola yang menganalisis gejala-gejala sosial budaya dengan menggunakan kebudayaan dari masyarakat yang bersangkutan untuk memperoleh gambaran mengenai pola-pola yang berlaku. Dari : Bogdan dan Taylor dalam Moleong, Metode Penelitian Kualitatif, Bandung : Remaja Rosda Karya, 2000, h. 13.

17 Adi Rianto,Op.cit.

18 Pasal 1 angka 1 UU 3 Tahun 1992 tentang Jaminan Sosial Tenaga Kerja.

${ }^{19}$ Pasal 2 ayat 3 Peraturan Pemerintah (PP) No. 14 Tahun 1993.

20 Pasal 1320 Kitab Undang-Undang Hukum Perdata (KUHPer) yang menyatakan, “ Untuk sahnya suatu perjanjian diperlukan empat syarat :
} 
Suatu perusahaan yang telah memenuhi persyaratan untuk melaksanakan dan memberlakukan program Jamsostek tetapi tidak menyelenggarakan, maka perusahaan tersebut akan mendapat sanksi administrasi seperti pencabutan izin usaha (setelah mendapat peringatan), denda $2 \%$ per bulan jika terlambat membayar iuran kepesertaan ${ }^{21}$, sanksi represif berupa hukuman kurungan selama-lamanya 6 (enam) bulan atau denda setinggi-tingginya Rp 50.000.000,- (lima puluh juta rupiah). ${ }^{22}$

Perusahaan yang telah berkewajiban menyelenggarakan program Jamsostek bagi tenaga kerjanya, selanjutnya bekerjasama dengan PT. Jamsostek sebagai Basan Usaha Milik Negara (BUMN) yaitu perusahaan persero, untuk program Jamsostek Jaminan Kecelakaan Kerja (JKK), Jaminan Kematian (JKM), Jaminan Hari Tua (JHT) dan Jaminan Pemeliharaan Kesehatan (JPK) ${ }^{23}$; mendaftarkan perusahaannya sebagai peserta program Jamsostek pada PT. Jamsostek dengan formulir yang telah disediakan.

Prosedur pendaftarannya adalah sebagai berikut :

1. Perusahaan menyampaikan formulir Jamsostek kepada PT. Jamsostek dalam waktu selambat-lambatnya 30 (tiga puluh) hari sejak diterimanya formulir dari PT. Jamsostek.

2. PT. Jamsostek, dalam rentang waktu paling lama 7 (tujuh) hari sejak formulir pendaftaran dan pembayaran iuran pertama diterima, menerbitkan dan menyampaikan kepada perusahaan terkait :

a. sertifikat kepesertaan sebagai tanda bahwa perusahaan terkait merupakan peserta PT. Jamsostek;

b. kartu peserta untuk masing-masing tenaga kerja perusahaan terkait sebagai kepesertaan dalam program Jamsostek;

3. Perusahaan terkait menyampaikan kepada masing-masing tenaga kerja kartu peserta program Jamsostek dalam waktu paling lambat 7 (tujuh) hari sejak diterima dari PT. Jamsostek. Kartu peserta tersebut, berlaku sampai dengan berakhirnya masa kepesertaan tenaga kerja yang bersangkutan dalam program Jamsostek.

4. Perusahaan terkait melaporkan kepada PT. Jamsostek, dalam waktu paling lambat 7 (tujuh) hari terkait terjadinya suatu perubahan di perusahaan terkait, seperti mengenai perubahan :

1. alamat perusahaan terkait;

2. kepemilikan perusahaan terkait;

3. jenis dan bidang usaha;

4. jumlah tenaga kerja dan keluarganya.

1. sepakat mereka yang mengikatkan dirinya,

2. kecakapan untuk membuat suatu perikatan,

3. suatu hal tertentu,

4. suatu sebab yang halal.

Kata-kata "tanpa paksaan macam apapun", penulis cantumkan mengingat hubungan ketenakerjaan antara perusahaan dan tenaga kerja, juga diikat dan terikat oleh suatu Kesepakatan Kerja Bersama (KKB). Relasikan pula dengan pasal 99 UU No. 13 Tahun 2003 yang menyatakan bahwa setiap tenaga kerja atau buruh dan keluarganya berhak untuk memperoleh Jamsostek, serta pasal 3 ayat 2 dan pasal 4 ayat 1 UU No. 3 Tahun 1992.

${ }^{21}$ Pasal 47 huruf a PP No. 14 Tahun 1993.

22 Pasal 29 UU No. 3 Tahun 1992.

${ }^{23}$ Amanat pasal 25 UU No. 3 Tahun 1992 dan PP No. 36 Tahun 1995. 
Selanjutnya, tenaga kerja perusahaan terkait mengajukan dan memenuhi syaratsyarat permohonan Jamsostek seperti :

1. Fotokopi Kartu Keluarga (KK) 1 (satu) lembar;

2. Fotokopi Kartu Tanda Penduduk (KTP) 1 (satu) lembar;

Selanjutnya, syarat tersebut di atas, diserahkan dan ditinjaklanjuti oleh perusahaan terkait melalui pihak perusahaan ke PT. Jamsostek setempat

Tenaga kerja perusahaan terkait yang telah menjadi peserta program Jamsostek wajib menyampaikan daftar susunan keluarga kepada perusahaan terkait (melalui kartu keluarga) termasuk segala perubahannya. Selanjutnya, PT. Jamsostek, dalam hal terjadi perubahan jumlah tenaga kerja dan keluarganya, menerbitkan kartu peserta tenaga kerja baru, kecuali tenaga kerja yang bersangkutan telah mempunyai kartu peserta.

5. Besarnya upah setiap tenaga kerja.

\section{KLASIFIKASI JAMSOSTEK}

\subsection{Klasifikasi bentuk Jamsostek}

\section{Jaminan Dalam Wujud Uang}

\section{a. Jaminan Kecelakaan Kerja (JKK)}

Kecelakaan kerja adalah kecelakaan yang terjadi berhubungan dengan hubungan kerja, termasuk penyakit yang timbul karena hubungan kerja, juga kecelakaan yang terjadi dalam perjalanan berangkat dari rumah menuju tempat kerja dan pulang ke rumah melalui jalan yang biasa atau wajar dilalui.

Iuran Jamsostek untuk JKK ditanggung sepenuhnya oleh perusahaan dengan klasifikasi sebagai berikut :

1. Kelompok I : 0,24 \% dari upah sebulan;

2. Kelompok II : 0,54 \% dari upah sebulan;

3. Kelompok III : 0,89 \% dari upah sebulan;

4. Kelompok IV :1,27 \% dari upah sebulan;

5. Kelompok V :1,74 \% dari upah sebulan.

Syarat bagi tenaga kerja yang menderita penyakit karena hubungan kerja, sekalipun hubungan kerjanya telah berakhir, adalah menyerahkan surat keterangan dokter/tenaga medis legal kepada perusahaan. Hak atas JKK tersebut, diberikan bila penyakit tersebut timbul dalam jangka waktu paling lama 3 (tiga) tahun sejak hubungan kerja berakhir.

Namun, kecelakaan yang terjadi pada saat tersebut di bawah ini, tidak termasuk sebagai kecelakaan kerja, yaitu :

1. waktu cuti;

2. di tempat perkemahan / mess;

3. di luar waktu kerja;

4. meninggalkan tempat kerja untuk keperluan pribadi;

5. disengaja.

JKK diberikan perusahaan kepada tenaga kerjanya yang tertimpa kecelakaan kerja berupa penggantian biaya, yang meliputi seperti berikut :

a. Biaya pengangkutan tenaga kerja yang mengalami kecelakaan kerja ke rumah sakit dan atau ke rumahnya, termasuk biaya pertolongan pertama pada kecelakaan. 
b. Biaya pemeriksaan, pengobatan, dan / atau perawatan selama di rumah sakit, termasuk rawat jalan.

c. Biaya rehabilitasi berupa alat bantu (orthese) dan / atau alat ganti (prothese) bagi tenaga kerja yang anggota badannya hilang atau tidak berfungsi akibat kecelakaan kerja.

d. Santunan berupa uang yang meliputi berikut :

1. santunan Sementara Tidak Mampu Bekerja (STMB).

- 4 (empat) bulan pertama sebesar $100 \%$ upah sebulan;

- 4 (empat) bulan kedua sebesar $75 \%$ upah sebulan;

- Bulan selanjutnya 50 \% upah sebulan.

2. Santunan cacat sebagian untuk selama-lamanya.

Dibayarkan secara sekaligus (lumpsum) sesuai tabel x 60 bulan upah.

3. Santunan cacat total untuk selama-lamanya, baik fisik maupun mental.

Dibayarkan secara sekaligus (lumpsum) dan secara berkala, dengan besarnya santunan adalah :

a. Santunan sekaligus sebesar $70 \%$ × 60 bulan upah;

b. Santunan berkala sebesar Rp 25.000,- (dua puluh lima ribu rupiah) selama 24 (dua puluh empat) bulan;

c. Santunan cacat kekurangan fungsi dibayarkan secara sekaligus.

Santunan kematian dibayarkan secara :

- Santunan sekaligus sebesar $60 \%$ x 60 bulan upah, sekurang-kurangnya sebesar jaminan kematian;

- Santunan berkala sebesar Rp 25.000,- (dua puluh lima ribu rupiah) selama 24 (dua puluh empat) bulan;

- Biaya pemakaman sebesar Rp 200.000,- (dua ratus ribu rupiah).

Berikut jenis pengobatan dan perawatan sesuai dengan biaya yang dikeluarkan terkait keterangan di atas :

1. Dokter

2. Obat

3. Operasi

4. Rontgen, Laboratorium

5. Perawatan Puskesmas, Rumah Sakit Umum Kelas I

6. Gigi

7. Mata

8. Jasa Tabib / Sinshe / Tradisional yang telah mendapat ijin resmi dari instansi yang berwenang.

Seluruh biaya yang dikeluarkan untuk 1 (satu) peristiwa kecelakaan dibayarkan maksimum Rp. 6.400.000,00 (enam juta empat ratus ribu rupiah). Sedangkan ongkos pengangkutan tenaga kerja dari tempat kejadian kecelakaan kerja ke Rumah Sakit diberikan penggantian biaya sebagai berikut:

1. Bilamana menggunakan jasa angkutan darat / sungai maksimum sebesar Rp.150.000,00 (seratus lima puluh ribu rupiah)

2. Bilamana menggunakan jasa angkutan laut maksimum sebesar Rp. 300.000,- (tiga ratus ribu rupiah) 
3. Bilamana menggunakan jasa angkutan udara maksimum sebesar Rp. 400.000,00 (empat ratus ribu rupiah)

Biaya JKK tersebut di atas, dibayar terlebih dahulu oleh perusahaan, sedangkan PT. Jamsostek, berdasarkan surat keterangan dari dokter / tenaga medis pemeriksa menetapkan dan membayar semua biaya dan santunan paling alama 1 (satu) bulan sejak diterimanya pengajuan pembayaran jaminan.

Tenaga kerja perusahaan dalam JKK yang dimaksud adalah melingkupi :

1). magang dan murid yang bekerja pada perusahaan, baik yang menerima upah atau tidak; dan untuk keperluan perhitungan pembayaran santunan JKK, pemagang dan murid dianggap menerima upah sebesar upah sebulan tenaga kerja perusahaan yang melakukan pekerjaan yang sama pada perusahaan yang bersangkutan.

2). mereka yang memborong pekerjaan, kecuali yang memborong adalah perusahaan; dan untuk keperluan perhitungan pembayaran santunan JKK, pemborong dianggap merima upah sebesar upah tertinggi dari tenaga kerja pelaksana yang bekerja pada perusahaan yang memborongkan pekerjaan.

Berikut ini kewajiban yang dilakukan perusahaan berkaitan dengan JKK:

1. memberikan pertolongan pertama pada kecelakaan bagi tenaga kerja perusahaan yang mengalami kecelakaan;

2. melaporkan setiap kecelakaan kerja yang menimpa tenaga kerja perusahaan kepada kantor Depnaker dan PT. Jamsostek setempat, sebagai laporan kecelakaan kerja tahap I dalam waktu tidak lebih dari $2 \times 24$ (dua puluh empat) jam terhitung sejak terjadinya kecelakaan;

3. melaporkan akibat kecelakaan kerja kepada kantor Departemen Tenaga Kerja (Depnaker) dan PT. Jamsostek setempat, sebagai laporan kecelakaan kerja tahap II dalam waktu tidak lebih dari 2 × 24 (dua kali dua puluh empat) jam setelah ada surat keterangan dokter pemeriksa atau dokter penasehat yang menyatakan bahwa tenaga kerja tersebut :

a. Sementara Tidak Mampu Bekerja (STMB) telah berakhir;

b. cacat sebagian untuk selama-lamanya;

c. cacat total untuk selama-lamanya, baik fisik maupun mental;

d. meninggal dunia.

Laporan akibat kecelakaan kerja tersebut sekaligus merupakan pengajuan pembayaran JKK kepada PT. Jamsostek dengan melampirkan :

1. fotokopi kartu peserta;

2. surat keterangan dokter pemeriksa atau dokter penasehat yang menerangkan mengenai tingkat kecacatan yang diderita tenaga kerja;

3. kuitansi biaya pengobatan dan pengangkutan;

4. dokumen pendukung lain yang diperlukan oleh PT. Jamsostek.

4. melaporkan penyakit yang timbul karena hubungan kerja dalam waktu tidak lebih dari 2 × 24 (dua kali dua puluh empat) jam setelah ada hasil diagnosis dari dokter pemeriksa.

Jika hal ini tidak dipatuhi oleh perusahaan, maka izin usaha perusahaan bisa dikenai sanksi berupa pencabutan izin usaha, sebagaimana isi pasal 47 PP No. 14 Tahun 1993. 
5. mengurus hak tenaga kerja yang tertimpa kecelakaan kerja kepada PT. Jamsostek sampai memperoleh hak-haknya.

Jika perusahaan tidak memenuhi kewajiban melaporkan kecelakaan kerja, melaporkan kesembuhan, cacat atau meninggal dunianya tenaga kerja yang kecelakaan tersebut atau tidak mengurus hak tenaga kerja yang kecelakaan tersebut kepada PT. Jamsostek, maka perusahaan bisa terkena hukuman kurungan selama-lamanya 6 (enam) bulan atau denda setinggi-tigginya Rp 50.000.000,- (lima puluh juta rupiah), sebagaimana yang telah diatur dalam pasal 29 UU No. 3 Tahun 1992.

Selama tenaga kerja di perusahaan yang tertimpa kecelakaan kerja belum mampu bekerja, perusahaan tetap membayar upah tenaga kerja tersebut, sampai penetapan akibat kecelakaan kerja yang dialami diterima semua pihak. Terkait dengan keadaan Sementara Tidak Mampu Bekerja (STMB), tenaga kerja perusahaan peserta Jamsostek berhak meerima santunan Sementara Tidak Mampu Bekerja (STMB) sebagai berikut :

1. 4 bulan pertama $100 \%$ upah;

2. 4 bulan kedua $75 \%$ upah;

3. Selanjutnya $50 \%$ upah.

Sedangkan PT. Jamsostek, mengganti Sementara Tidak Mampu Bekerja (STMB) kepada perusahaan yang telah membayar upah tenaga kerja tersebut dalam hal :

1. santunan yang dibayarkan oleh PT. Jamsostek lebih besar dari yang dibayarkan oleh perusahaan, maka selisihnya dibayarkan langsung kepada tenaga kerja;

2. penggantian santunan yang dibayarkan oleh PT. Jamsostek lebih kecil dari upah yang telah dibayarkan oleh perusahaan, maka selisihnya tidak dimintakan pengembaliannya kepada tenaga kerja.

\section{b. Jaminan Hari Tua (JHT)}

Iuran Jamsostek untuk Jaminan Hari Tua (JHT) adalah sebesar 5,70 \% dari upah sebulan, dengan perincian 3,70\% ditanggung oleh perusahaan, dan $2 \%$ ditanggung oleh tenaga kerja.

Iuran JHT yang ditanggung tenaga kerja perusahaan, diperhitungkan langsung dari upah bulanan tenaga kerja yang bersangkutan dan penyetorannya kepada PT. Jamsostek dilakukan oleh pihak perusahaan. Selanjutnya, JHT dibayarkan kepada tenaga kerja perusahaan, secara sekaligus atau berkala atau sebagian dan berkala berdasarkan pilihan tenaga kerja perusahaan yang bersangkutan dengan persyaratan sebagai berikut :

a. telah mencapai usia 55 (lima puluh lima) tahun; atau

b. cacat total tetap setelah ditetapka oleh dokter walaupun belum 55 (lima puluh lima) tahun;

c. meninggalkan wilayah Indonesia selamanya;

d. meninggal dunia;

e. tidak bekerja lagi.

Dalam hal tenaga kerja perusahaan meninggal dunia, JHT dibayarkan kepada janda atau dudanya, atau anak yatim piatunya. Besarnya adalah keseluruhan iuran yang telah disetor beserta hasil pengembangannya.

Tenaga kerja perusahaan yang telah mencapai usia 55 (lima puluh lima) tahun tetapi masih tetap bekerja, dapat memilih untuk menerima pembayaran JHT pada usia 
55 (lima puluh lima) tahun atau pada saat tenaga kerja yang bersangkutan berhenti bekerja. Dalam hal tenaga kerja perusahaan, tetapi tetap bekerja, maka kepesertaannya dalam program Jamsostek tetap dilanjutkan dan perusahaan tetap membayar segala kewajiban yang berhubungan dengan kepesertaan tenaga kerja dalam Jamsostek tersebut.

Tenaga kerja perusahaan yang cacat total tetap untuk selama-lamanya sebelum mencapai usia 55 (lima puluh lima) tahun berhak mengajukan pembayaran JHT kepada PT. Jamsostek. Selanjutnya PT. Jamsostek akan menetapkan besarnya JHT paling lambat 30 (tiga puluh) hari sebelum tenaga kerja mencapai 55 (lima puluh lima) tahun dan memberitahukan kepada tenaga perusahaan yang bersangkutan.

Penyetoran iuran yang dilakukan oleh perusahaan kepada PT. Jamsostek dilakukan setiap bulan dan disetor paling lama 15 (lima belas) bulan berikutnya dari bulan iuran yang bersangkutan. Jikalau perusahaan terlambat melakukan pembayaran iuran, maka perusahaan dikenakan denda sebesar $2 \%$ untuk setiap bulan keterlambatan, yang dihitung dari iuran yang seharusnya dibayar (menjadi tanggungan perusahaan) ${ }^{24}$. Dalam hal terjadi kelebihan atau kekurangan pembayaran iuran, PT. Jamsostek memberitahukan secara tertulis kepada perusahaan dalam tempo waktu paling lambat 7 (tujuh) hari sejak diterimanya iuran. Kelebihan atau kekurangan pembayaran iuran dapat diperhitungkan dengan pembayaran iuran bulan berikutnya.

\section{c. Jaminan Kematian (JKM)}

Jaminan Kematian (JKM) ini, berhak diterima oleh keluarga tenaga kerja perusahaan yang meninggal dunia bukan akibat kecelakaan kerja. Jikalau tenaga kerja perusahaan peserta Jamsostek meninggal akibat kecelakaan kerja, maka santunan Jamsostek yang menjaminnya adalah JKK, kecuali jika jumlah santunan JKK lebih rendah dari jumlah santunan JKM, maka keluarganya akan mendapatkan santuan dari JKM.

Program Jamsostek JKM ini berwujud tabungan selama masa kerja yang dibayarkan kembali pada usia 55 tahun atau sebelum itu jika mengalami cacad tetaptotal atau meninggal dunia atau masalah Pemutusan Hubungan Kerja (PHK) dengan masa kerja di perusahaan minimal 5 tahun. JKM ini, dapat diambil setelah memenuhi masa kepesertaan 5 tahun dan masa tunggu 6 bulan.

Iuran Jamsostek untuk Jaminan Kematian (JKM) adalah sebesar 0,30 \% dari upah sebulan yang ditanggung sepenuhnya oleh perusahaan. Dan, santunan JKM tersebut meliputi :

1. biaya pemakaman yaitu sebesar $\operatorname{Rp} 200.000,-$ (dua ratus ribu rupiah);

2. santunan berupa uang sebesar $\operatorname{Rp} 1.000 .000$,- (satu juta rupiah).

Penerima santunan kematian di perusahaan dari JKM menurut tingkatan atau urutan yang berhak adalah sebagai berikut :

1. janda atau duda

2. anak

3. orang tua

4. cucu

${ }^{24}$ Memenuhi substansi pasal 10 ayat 3 dan pasal 47 b PP No. 14 Tahun 1993. 
5. kakek atau nenek

6. saudara kandung

7. mertua

Dalam hal janda atau duda atau anak tidak ada, maka santunan JKM dibayar sekaligus kepada keturunan sedarah yang ada dari tenaga kerja perusahaan menurut garis lurus ke bawah dan garis lurus ke atas, dihitung sampai derajat kedua. Dalam hal tenaga kerja perusahaan tidak mempunyai keturunan sedarah, maka santuan JKM dibayarkan sekaligus kepada pihak yang ditunjuk oleh tenaga kerja perusahaan dalam wasiatnya. Jikalau tidak ada wasiat, maka biaya pemakaman dibayarkan kepada perusahaan atau pihak lain dari PT. Jamsostek guna pengurusan pemakaman. Bila tenaga kerja perusahaan yang meninggal dunia bukan karena kecelakaan kerja, tetapi tenaga kerja magang atau murid atau mereka yang memborong pekerjaan di perusahaan, maka keluarga yang ditinggalkan tidak berhak atas santunan JKM. Hal ini merupakan realisasi dari peraturan pasal 22 ayat 5 PP No. 14 Tahun 1993.

Pihak keluarga yang berhak akan mendapat pembayaran santunan kematian dari PT. Jamsostek setelah mengajukan pembayaran iuran kematian dengan disertai buktibukti, seperti kartu peserta dan surat keteragan kematian.

\section{Jaminan Berupa Pelayanan}

\section{a. Jaminan Pemeliharaan Kesehatan (JPK)}

Jaminan Pemeliharaan Kesehatan merupakan jaminan sebagai upaya penanggulangan dan pencegahan gangguan kesehatan yang memerlukan pemeriksaan, pengobatan dan/atau perawatan termasuk kehamilan. Program Jaminan Pemeliharaan Kesehatan dapat diselenggarakan oleh perusahaan sesuai dengan ketentuan dasar Jaminan Sosial Tenaga Kerja atau lebih baik daripada Jaminan Pemeliharaan Kesehatan Dasar Jaminan Sosial Tenaga Kerja, sebagaimana yang tercantum dalam Pasal 2 Ayat (3) Peraturan Pemerintah Nomor 14 Tahun 1993 Tentang Penyelenggaraan Jaminan Sosial Tenaga Kerja.

Dengan perkataan lain, dalam hal melaksanakan Jamsostek, perusahaan bekerjasama dengan PT. Jamsostek dengan ruang lingkup utama untuk program Jamsostek Jaminan Kecelakaan Kerja (JKK), Jaminan Kematian (JKM), dan Jaminan Hari Tua (JHT). Khusus untuk Jaminan Pemeliharaan Kesehatan (JPK), baru bersifat wajib bagi perusahaan yang belum memberikan pelayanan kesehatan kepada tenaga kerja. Sehingga dalam penyelenggaraan JPK ini, suatu perusahaan lazim dapat merangkap sebagai badan penyelenggara sekaligus pengusaha, dengan bekerjasama dengan instansi kesehatan setempat.

JPK diselenggarakan secara terstruktur, terpadu dan berkesinambungan serta bersifat menyeluruh, yang meliputi :

a. pelayanan peningkatan kesehatan;

b. pencegahan;

c. pengobatan atau penyembuhan penyakit;

d. pemulihan kesehatan atau perawatan.

Dalam pelaksanaan JPK ini, tenaga kerja suatu perusahaan yang bersangkutan atau suami atau isteri atau anak yang memerlukan pelayanan gawat darurat dapat langsung memperoleh pelayanan dari pelaksana pelayanan kesehatan atau rumah sakit yang 
terdekat dengan menunjukkan kartu pemeliharaan kesehatan dan dalam waktu 7 (tujuh) hari sesuai dengan standar biaya yang setelah ditetapkan ${ }^{25}$. Dalam hal biaya rawat inap melebihi ketentuan yang ditetapkan, maka selisih biayanya menjadi tanggungjawab tenaga kerja sendiri.

Besar iuran Jamsostek untuk JPK sebesar $6 \%$ dari upah sebulan bagi tenaga kerja yang berkeluarga dan $3 \%$ dari upah sebulan bagi tenaga kerja yang bujang, yang ditanggung oleh pengusaha ${ }^{26}$.

Untuk lebih jelas terkait penjelasan tersebut di atas, maka berikut ikhtisar prosedur klaim Jamsostek :

\section{Mencapai Usia 56 Tahun :}

1. Kartu Peserta Jamsostek (KPJ) asli

2. Copy KTP tenaga kerja.

3. Copy kartu keluarga

\section{Meninggal Dunia :}

1. KPJ asli.

2. Copy KTP tenaga kerja \& ahli waris.

3. Copy kartu keluarga.

4. Surat keterangan kematian dari pejabat yang berwenang.

\section{Cacat Total Tetap :}

1. KPJ asli.

2. Copy KTP.

3. Copy kartu keluarga.

4. Surat keterangan dokter yang menyatakan cacat.

\section{Meninggalkan Republik Indonesia :}

1. KPJ asli.

2. Copy KTP.

3. Copy pasport.

4. Copy visa bagi tenaga kerja WNI.

5. Surat pernyataan tidak bekerja lagi di Indonesia.

\section{Menjadi anggota ABRI/Pegawai Negeri Sipil :}

1. KPJ asli.

2. Copy KTP.

3. Copy kartu keluarga.

4. Copy surat keputusan pengangkatan sebagai PNS/ABRI.

VI. Keluar dari perusahaan dengan masa kepesertaan minimal 5 tahun

1. KPJ asli

2. Copy KTP.

3. Copy kartu keluarga.

4. Copy SK Pemberhentian/PHK dari perusahaan.

\section{Lain-lain (SK Menaker 117/1986) :}

1. KPJ asli.

2. Copy KTP.

25 Pasal 41 ayat 3 PP Tahu 1993.

26 Pasal 9 PP No. 14 Tahun 1993. 
3. Copy kartu keluarga.

4. Copy keterangan tidak terlibat organisasi.

Berkait pelaksanaan Jamsostek seperti tersebut di atas, berikut kendala-kendala beserta solusi atas hambatan dalam pelaksanaan Jamsostek.

Jenis-jenis perusahaan di Indonesia, dapat dikelompokkan menjadi 3 (tiga) yaitu perusahaan besar, sedang dan kecil. Menurut R. Goenawan Oetomo'27, hambatan pelaksanaan Jamsostek di Indonesia pada umumnya adalah sebagai berikut :

1. Perusahaan besar

Perusahaan besar merupakan perusahaan yang secara ekonomis kuat dan mempunyai manajemen yang mapan, sehingga diharapkan adanya administrasi yang baik. Dengan demikian, akan menjadikan lebih mudah melaksanakan ketentuanketentuan Jamsostek, yang akan lebih menjadi lancar lagi dengan adanya monitoring atau pengawasan dari pihak yang berwenang. Namun dalam praktiknya, hal tersebut tidak mulus terlaksana. Hal tersebut disebabkan oleh mekanisme pengawasan dari instansi yang berwenang yang masih perlu disempurnakan lebih baik sehingga dapat mengimbangi sistem administrasi yang digunakan perusahaan tersebut.

2. Perusahaan sedang

Perusahaan sedang, administrasinya agak lebih sederhana, sehingga masalah Jamsostek dapat dimonitoring dengan perangkat administrasi yang ada dari instansi yang berwenang.

3. Perusahaan kecil

Perusahaan kecil letaknya lebih mengelompok di permukiman, sebagai usaha industri perumahan yang jumlahnya cukup besar, sehingga masalah Jamsostek dalam lingkup ini, menjadi lebih rumit. Hal tersebut dikaremakan oleh karena selain kemampuan ekonominya terbatas, biasanya pengelolaannya juga diserahkan pada kemampuan seadanya. Dengan demikian, kondisi administrasi jauh dari sederhana, bahkan mungkin acak-acakan. Berefek pada masalah mengenai status buruh, besarnya upah, jumlah buruh, dan jenis pekerjaan yang dilakukan. Keseluruhannya dalam kondisi campur aduk dan menyulitkan bagi kepentingan monitoring atau pengawasan. Efek lanjutannya adalah sulitnya penerapan atau pelaksanaan Jamsostek pada tenagatenaga kerjanya mengingat Jamsostek itu meliputi hal yang semakin luas seperti terhadap :

1. gangguan sosial ekonomi yang diakibatkan oleh sakit, kehamilan, kecelakaan, keadaan cacat, usia lanjut, kematian;

2. penyediaan layanan medis;

3. bantuan kepada keluarga (janda dan anak-anak).

Dari keterangan tersebut di atas, R. Goenawan Oetomo 28 , menyimpulkan bahwa kesulitan atau hambatan pelaksaan Jamsostek pada umumya berupa :

1. kemampuan ekonomis perusahaan;

2. administrasi yang tidak / kurang memadai;

3. kemampuan monitoring / pengawasan yang berwenang.

27 R. Goenawan Oetomo, Pengantar Hukum Peruburuhan dan Hukum Perburuhan Indonesia, Jakarta : Grhadhika Binangkit Press, 2004.

${ }^{28}$ R. Goenawan Oetomo. Ibid. hal. 73. 
Dan, berikut hambatan pelaksanaan Jamsostek di suatu perusahaan selain yang sudah tersebut di $\operatorname{atas}^{29}$ :

1. Adanya tenaga kerja perusahaan yang sakit mendadak atau memerlukan jasa kesehatan mendadak, tetapi sedang berada di luar wilayah lingkup kerja JKK.

Hal ini bisa menjadi suatu hambatan manakala lingkup kerjasama di bidang kesehatan oleh perusahaan tersebut masih hanya dengan instansi kesehatan setempat (lokal). Sedang wilayah kerja para tenagakerjanya interlokal.

2. Tenaga kerja suatu perusahaan yang mayoritas berasal dan berpola pikir sebagaimana masyarakat pedesaan.

Dalam pola pikir masyarakat pedesaan yang masih mengental kebiasaan manakala sakit, diperiksakan atau diobatkan pada tenaga medis seadanya yang fasilitas administrasinya lebih sering bersifat kekeluargaan, menjadikan pembayaran tanpa tanda bukti tetapi secara langsung, pemberian informasi jenis obat tanpa resep tertulis, dan hasil pemeriksaan yang hanya diucapkan secara lisan tanpa hitam di atas putih. Padahal, ada syarat bukti otentik yang mesti dipenuhi oleh tenaga kerja suatu perusahaan peserta Jamsostek dalam mengajukan pengklaiman.

3. adanya tenaga kerja suatu perusahaan yang belum terampil mengetahui dan memahami prosedur dan syarat-syarat pengajuan klaim Jamsostek.

Hal ini otomatis menghambat kelancaran proses pengklaiman Jamsostek dari PT. Jamsostek, karena rentang waktu yang diperlukan untuk memenuhi persyaratan pengklaiman menjadi lebih panjang. Sebagai misal, dalam proses pengklaiman JKM, maka pihak yang berwenang semestinya menyerahkan syarat-syarat berikut kepada perusahaan : Kartu Peserta Jamsostek (KPJ) asli, copy Kartu Tanda Penduduk (KTP) tenaga kerja dan ahli waris, copy Kartu Keluarga (KK) dan surat keterangan kematian dari pejabat yang berwenang. Namun karena kekurang pengetahuan dan pemahaman dari pihak tenaga kerja suatu perusahaan yang bersangkutan, bisa menjadikan syarat tersebut baru dapat dipenuhi setelah pihak yang bersangkutan lebih dari 2 (dua) kali menyerahkan persyaratan tersebut.

4. adanya banyak unsur Jamsostek yang semestinya wajib dilaporkan oleh suatu perusahaan ke PT. Jamsostek, namun karena ketidaktahuannya tenaga kerja terkait perkara hal itu, proses pelaporannya menjadi terhambat atau bahkan menyebabkan kadaluwarsanya proses pegklaiman

5. Tenaga kerja suatu perusahaan yang mayoritas berasal dari daerah pedesaaan dengan budaya malunya yang kental, bisa menyebabkan tidak adanya keberanian untuk mengurusi pengklaiman ke PT. Jamsostek langsung, karena masih didominasinya rasa malu dalam diri mereka sehingga kurang memperlancar proses pencairan pengklaiman Jamsostek

6. ketidakmauan tenaga kerja untuk mengikuti atau mendaftar sebagai peserta Jamsostek karena khawatir gajinya akan banyak terpotong-potong (sangat berkurang).

Pelaksanaan program Jamsostek yang mengalami kendala yang bukan dikarenakan oleh masalah keadministrasian perusahaan ataupun oleh kesulitan/minimalnya ekonomi

${ }^{29}$ Anik Iftitah, Laporan PKL, Pelaksanaan Jamsostek Sebagai Bentuk Perlindungan Sosial Bagi Tenaga Kerja, PS. Ilmu Hukum, FH-Univ. Islam Balitar, Blitar, 2010. 
atau pemasukan perusahaan, tetapi lebih dikarenakan karena faktor kekurang pengetahuan dan pemahaman tenaga kerja suatu perusahaan akan Jamsostek itu sendiri, sehingga bisa berefek pada kekuranglancaran realisasi pelaksanaan Jamsostek, bisa diatasi melalui beberapa tindakan-tindakan alternatif antara lain sebagai berikut ${ }^{30}$ :

1. Mengadakan kerjasama bipartit dengan Dinas Sosial Tenaga Kerja (Dinsosnaker) setempat.

Kerjasama bipartit dengan Dinsosnaker setempat yang dilakukn oleh perusahaan dapat dilakukan misal dengan melakukn perundingan atau musyawarah mufakat untuk mencari jalan keluar (solving problem) atau menyelesaikan segala persoalan yang terjadi di perusahaan terkait dengan tenag kerjanya. Aplikasi dari kerjasama tersebut adalah dengan mengadakan pengawasan dan pengecekan atas segala alat peralatan perusahaan demi keselamatan dan keamanan kerja tenaga kerja perusahaan, sehingga meniadakan atau meminimalisir tingkat kecelakaan kerja di tempat kerja akibat hubungannya dengan penggunaan alat peralatan kerja di perusahaan.

2. selalu mengadakan meeting dengan tenaga kerja setiap bulan.

Menjalin dan menyampaikan informasi serta pelaksanaan terkait program Jamsostek secara kekeluargaan (face to face) langsung kepada pihak tenaga kerja yang bersangkutan, mendengarkan langsung segala persoalan yang dihadapi oleh tenaga kerja perusahaan (identifikasi masalah), kemudian memberikan penjelasan segala keterangan terkait pelaksaaan Jamsostek (sosialisasi program-program realisasi Jamsostek secara jelas, detail dan terperinci) bagi seluruh tenaga kerja perusahaan secara kontinyu (minimal sekali dalam satu bulan), dengan tujuan agar segala ketidaklancaran dan anasir-anasir negatif terkait pelaksanaan Jamsostek pada perusahaan hilang dari pikiran tenaga kerja perusahaan yang irasional dan statis.

Melalui strategi pemecahan masalah atas hambatan-hambatan yang ada tersebut di atas, pihak perusahaan secara otomatis berperan pula dalam meningkatkan kwalitas pengetahuan dan pemahaman Jamsostek pada tenaga kerjanya, sehingga tidak muncul lagi anasir-anasir negatif yang merugikan pihak tenaga kerja sendiri.

Dengan dapat dilaksanakannya Jamsostek bagi tenaga kerja perusahaan, otomatis akan meningkatkan tingkat harmonisasi hubungan antara kedua belah pihak. Dipihak tenaga kerja perusahaan, hal tersebut menggugurkan segala kekhawatiran ketidakpastian resiko tenaga kerja perusahaan dimasa depan karena hak-hak dan perlindungan yang mendasar bagi tenaga kerja perusahaan terpenuhi. Pada saat yang bersamaan, pelaksaaan Jamsostek tersebut merupakan satu bentuk strategi pendongkrakan kemajuan perusahaan sendiri, karena kuat daya topang operasional usahanya (tingkat loyalitas tenaga kerjanya), mewujudkan kondisi yang kondusif bagi pengembangan dunia usahanya.

Dari penjabaran perwujudan pelaksanaan program Jamsostek seperti yang telah terjabarkan di atas, maka peran Jamsostek dalam rangka pembangunan manusia Indonesia seutuhnya dan pembangunan masyarakat Indonesia seluruhnya adalah sebagai berikut:

a. Jaminan Sosial Tenaga Kerja Sebagai Manifestasi Kepastian Hukum Guna Menciptakan Keseimbangan Hubungan Kerja yang Mewujudkan Keadilan

${ }^{30}$ Ibid. 
Adalah suatu kepastian, bahwa tiap-tiap perusahaan yang telah memenuhi kriteria wajib melaksanakan program Jamsostek kepada setiap tenaga kerjanya, memberlakukan program Jamsostek dengan nilai prosentase nominal yang tetap dan pasti (tidak mengandung penafsiran yang berbeda-beda) seperti yang telah terjabarkan di atas. Hal ini jelas merupakan suatu manifestasi (perwujudan) kepastian hukum.

Lebih jauh terkait hal tersebut di atas, dalam suatu hubungan kerja, pengusaha sebagai pihak pemberi kerja dan upah, lazim mempunyai kedudukan sosial ekonomi dan latar belakang pendidikan yang lebih tinggi dalam melakukan hubungan hukum sedangkan tenaga kerja lazim merupakan pihak yang mempunyai kondisi yang lemah dalam segala aspeknya. Pemegang otoritas utama dalam kebebasan melakukan hubungan hukumpun, ada ditangan pihak pengusaha. Adanya kondisi dan peluang keadaan yang timpang tersebut, jika dibiarkan tanpa tatanan yang bermuatan kepastian, tentunya akan mewujudkan suatu realita yang terlalu dominan disatu pihak dan pihak lain menjadi pihak yang terpinggirkan (termarginalkan). Suatu kondisi yang bisa menghantarkan pada realita terwujudnya praktek exploitation dhe lhome par lhome antara pihak perusahaan terhadap para tenaga kerja.

Dengan pemberlakuan program Jamsostek yang memanifestasikan kepastian hukum pada suatu perusahaan, ketimpangan tersebut di atas, dapat diubah menjadi suatu tatanan dalam hubungan kerja yang seimbang, proporsional. Melalui Jamsostek, kepentingankepentingan antar perusahaan dan tenaga kerja ditata, sebagai suatu langkah progresif untuk menata kepentingan-kepentingan yang ada, perwujudan dari teori Roscoe Pound tentang law as a tool of social engineering 31 .

Hal tersebut dapat dipahami mengingat dalam rangka pelaksanakan program Jamsostek, perusahaan harus menjalin hubungan yang baik secara kekeluargaan dan menciptakan suasana atau lingkungan kerja yang baik dan nyaman terhadap tenaga kerjanya. Pelaksanaan program Jamsostek tersebut, muskil terterapkan manakala tidak ada kepercayaan dan keloyalitasan pada pihak tenaga kerja terhadap perusahaan. Sedangkan bagi perusahaan, pelaksanaan program Jamsostek ini bersifat wajib/mengikat yang mengandung sanksi administrasi dan represif jika tidak diberlakukan. Disinilah letak tingginya posisi peran tenaga kerja sehingga menghilangkan peluang dijadikannya sebagai pihak yang termaginalkan. Dengan kata lain, antara perusahaan dan tenaga kerja, harus tercipta suatu hubungan yang seimbang.

Dalam pola hubungan kerja yang seimbang, tenaga kerja kedudukannya adalah sebagai partner perusahaan guna mewujudkan tujuan usaha perusahaan. Memberikan dan memberlakuan Jamsostek pada tenaga kerja, otomatis akan dapat lebih merangsang tenaga kerja untuk lebih produktif, sehingga perusahaanpun semakin maju progresif. Di pihak tenaga kerja, jaminan sosial berperan sangat membantu kehidupan tenaga kerja dan keluarganya terutama dalam menghadapi berbagai peristiwa sosial semisal sakit, perkawinan, kematian dan lain-lain. Hal tersebut dapat dimaklumi karena dalam situasi dan kondisi seperti tersebut, pada umumnya semangat dan gairah kerja serta prestasi pekerja tersebut cenderung turun, mengingat dalam menghadapi peristiwa sosial tersebut diperlukan biaya ekstra.

${ }^{31}$ Dr. Bernard L. Tanya, SH. MH., Teori Hukum Strategi Tertib Manusia Lintas Ruang dan Generasi, Surabaya : CV Kita, 2007, h.180. 
Dengan terterapkannya kaidah kepastian hukum sehingga terbentuk pola hubungan kerja antara perusahaan dan tenaga kerja yang seimbang dan proporsional sebagai ruh dari kaidah adil yaitu mampu berdiri di tengah-tengah antara dua perkara sebagaimana teori adil menurut kaidah fiqhi, memenuhi selera asas keseimbangan Prof. Kranenburg dan selaras dengan teori keadilan Aristoteles yaitu memberi kepada tiap-tiap orang apa yang berhak ia terima ${ }^{32}$, adanya wujud realita yang melaksanakan idea keseimbangan antara hak dan kewajiban 33 , otomatis terpenuhilah/terwujudlah tujuan hokum ketenagakerjaan guna mewujudkan masyarakat sejahtera, adil, makmur dan merata, baik materiil maupun spiritual.

\section{b. Jaminan Sosial Tenaga Kerja sebagai Perwujudan Penerapan Nilai-Nilai Hukum (Law In Action)}

Dari penjabaran pelaksanaan Jamsostek di Indonesia sebagaimana yang telah tersebut di atas, maka dapat kita ketahui bahwa Jamsostek merupakan suatu wujud peraturan yang sistematis, bukan merupakan suatu peraturan yang bersifat kondisional, tapi merupakan suatu peraturan yang telah disosialisasikan dan mengikat untuk terlaksanakan dalam ranah wilayah Negara Indonesia, yang tidak berlaku surut, dimana substansinya bersifat jelas dan terperinci, dapat dimengerti oleh pihak terkait (perusahaan dan tenaga kerja), tidak mengandung unsur pelaksanaan yang impossible, tidak bertentangan dengan peraturan perundang-undangan lain di Indonesia, bahkan diberlakukan dan dilaksanakan dengan berinduk hukum pada Pancasila dan UUD 1945, bersifat tetap, tidak sering berubah-ubah, dan wujud pelaksanaannya didasarkan dan berdasar pada peraturan-peraturan yang telah dibuat.

Sifat-sifat Jamsostek seperti di atas, merupakan perwujudan penerapan nilai-nilai hukum (law in action) sesuai 8 (delapan) prinsip legalitas yang diutarakan oleh Lon L. Fuller ${ }^{34}$. Kedelapan prinsip legalitas ini, merupakan tolak ukur penilaian besar kecilnya peranan hukum dalam melindungi hak-hak manusia (tenaga kerja). Kegagalan untuk mewujudkan salah satu dari nilai-nilai tersebut bukan hanya menyebabkan timbulnya sistem hukum yang jelek, tetapi lebih dari itu adalah samasekali tidak dapat disebut hukum ${ }^{35}$.

\section{i. Jaminan Sosial Tenaga Kerja sebagai Satu Teknik Perwujudan Cita Hukum Ketenagakerjaan di Indonesia}

Tenaga kerja sebagai pelaksana utama proses produktifitas dalam suatu perusahaan, mempunyai peran vital dalam meningkatkan tingkat produktifitas nasional. Dengan menerapkan Jamsostek yang melindungi tenaga kerja pada saat terjadinya peristiwaperistiwa sosial yang pada umumnya memerlukan banyak biaya, otomatis Jamsostek berperan dalam penjagaan atas kestabilan semangat kinerja tenaga kerja. Terjaganya kestabilan tingkat kinerja tenaga kerja, otomatis akan meningkatkan tingkat produktifitas

\footnotetext{
32 Prof. Dr. Baharuddin Lopa, S.H., Permasalahan Pembinaan dan Penegakan Hukum di Indonesia, Jakarta : Bulan Bintang, 1987, h.126

${ }^{33}$ Hal ini sesuai dengan hadits Nabi Muhammad SAW, Khairul-umuri ausathuha, yang berarti sebaikbaik perbuatan adalah yang seimbang. Ibid. h. 3 .

${ }^{34}$ Keterangan dalam Bab I Pendahuluan h. 4.

${ }_{35}$ Op.Cit. Satjipto Rahardjo SH.
} 
yang akhirnya adalah meningkatkan tingkat kesejahteraan tenaga kerja dan/atau sekaligus keluarga tenaga kerja, yang selanjutnya turut andil dalam meningkatkan pertumbuhan perekonomian bagi kesejahteraan masyarakat dan perkembangan masa depan bangsa Indonesia. Masyarakat sejahtera, adil, makmur, dan merata, baik materiil maupun sppiritual tidak dapat dicapai apabila tenaga kerja dan keluarganya tidak sejahtera. Meningkatkan kesejahteraan tenaga kerja dan keluarganya merupakan bagian dalam rangka mewujudkan kesejahteraan masyarakat Indonesia. ${ }^{36}$ Selaras dengan cita tujuan pembangunan hukum ketenagakerjaan di Indonesia, yaitu untuk memberikan perlindungan kepada tenaga kerja dalam mewujudkan kesejahteraan dan meningkatkan kesejahteraan tenaga kerja dan keluarga. Dari penjelasan ini, maka dapat dikatakan bahwa jaminan sosial tenaga kerja berperan sebagai satu teknik ${ }^{37}$ perwujudan cita hukum ketenagakerjaan di Indonesia.

\section{KESIMPULAN}

Peran program jaminan sosial tenaga kerja yang berupa jaminan kecelakaan kerja, jaminan kematian, jaminan hari tua, dan jaminan pemeliharaan kesehatan dalam pembangunan hukum ketenagakerjaan di Indonesia adalah :

a. Jaminan Sosial Tenaga Kerja Sebagai Manifestasi Kepastian Hukum Guna Menciptakan Keseimbangan Hubungan Kerja yang Mewujudkan Keadilan

b. Jaminan Sosial Tenaga Kerja sebagai Perwujudan Penerapan Nilai-Nilai Hukum (Law in Action)

c. Jaminan Sosial Tenaga Kerja sebagai Satu Teknik Perwujudan Cita Hukum Ketenagakerjaan di Indonesia

Jaminan sosial tenaga kerja yang mempunyai peranan sebagai penyeimbang kepentingan antara perusahaan dan tenaga kerja, sebagai perwujudan penerapan nilai-nilai hukum (law in action) dan sebagai satu teknik dalam perwujudan cita hukum ketenagakerjaan di Indonesia, perlu dilaksanakan secara konsekwen agar benar-benar dapat menjadi pendorong dan pengarah tercapainya masyarakat adil dan makmur.

\footnotetext{
${ }^{36}$ Hardijan Rusli..h. 17. Op. Cit

${ }^{37}$ Mac Iver. The Web of Government. New York. "Technique is ability to use the object men and tools desire the wants to the subject".
} 


\section{DAFTAR PUSTAKA}

\section{Buku:}

Al-Quran dan Terjemahannya, Departemen Agama RI, Surabaya : Mekar Surabaya, 2004.

Asikin, Zainal dkk., Dasar-Dasar Hukum Perburuhan, Jakarta : PT Raja Grafindo, 2008.

Husni, Lalu, Perlindungan Buruh (Arbeidsbescherming., Jakarta : PT Raja Grafindo Persada, 2008.

Iftitah, Anik, Laporan PKL, Pelaksanaan Jamsostek Sebagai Bentuk Perlindungan Sosial Bagi Tenaga Kerja, PS. Ilmu Hukum, FH-Univ. Islam Balitar, Blitar, 2010.

Iver, Mac., The Web of Government, New York.

Kamus Besar Bahasa Indonesia, Jakarta : Departemen Pendidikan dan Kebudayaan RI, 1998.

Khakim, Abdul, Pengantar Hukum Ketenagakerjaan Indonesia, Bandung : PT Citra Aditya Bakti, 2007.

Lopa, Baharuddin, Pembinaan dan Penegakan Hukum di Indonesia, Jakarta : Bulan Bintan, 1987. Permasalahan

Moleong, Metode Penelitian Kualitatif, Bandung : Remaja Rosda Karya, 2000.

Oetomo, R. Goenawan, Pengantar Hukum Peruburuhan dan Hukum Perburuhan Indonesia. Jakarta : Grhadhika Binangkit Press, 2004.

Rahardjo, Satjipto, Hukum dan Masyarakat, Bandung : Angkasa, 1981.

Rianto, Adi, Metodologi Penelitian Sosial \& Hukum, Jakarta : Granit, 2004.

Rusli, Hardijan, Hukum Ketenagakerjaan 2003, Jakarta : Ghalia Indonesia, 2004.

Soekanto, Soerjono, Pengantar Peneletian Huku,. Jakarta : Universitas Indonesia Press, 1986.

Soekarno, Doktrin Revolusi Indonesia, Surabaya : CV. Narsih, 1962.

Sunggono, Bambang. Metodologi Penelitian Hukum. Jakarta : Raja Grafindo, 2005.

Susmayanti, Riana, Diktat Hukum Perburuhan dan Ketenagakerjaan, Blitar : Universitas Islam Balitar, 2007.

Tanjung, H. Bahdin Nur dan H. Ardial, Pedoman Penulisan Karya Ilmiah (Proposal Skripsi, dan Tesis) dan Mempersiapkan Diri Menjadi Penulis Artikel Ilmiah, Jakarta : Kencana, 2007.

Tanya, Bernard L, Teori Hukum Strategi Tertib Manusia Lintas Ruang dan Generasi, Surabaya : CV Kita, 2007.

\section{Peraturan dan Perundang-undangan}

Undang-Undang Dasar 1945 Amandemen Ke-Empat.

Kitab Undang-Undang Hukum Perdata.

Undang-Undang Nomor 3 Tahun 1992 tentang Jaminan Sosial Tenaga Kerja.

Undang-Undang Nomor 13 Tahun 2003 tentang Ketenagakerjaan.

Peraturan Pemerintah (PP) No. 14 Tahun 1993 tentang Penyelenggaraan Jaminan Sosial Tenaga Kerja.

\section{Website}

S. Anwary. Makalah Penegakan Negara Hukum di Republik Indonesia. Blog.unila.ac.id/pdih/.../tema-dan-topik-seminar-hukum-nasional.pdf. Diakses pada Juni 2010. 
Dokumen Rencana Pembangunan Jangka Menengah Nasional (RPJMN) 2010-2014. Penjabaran visi, misi dan program aksi pembangunan nasional Presiden / Wakil Presiden Susilo Bambang Yudhoyono - Boediono. www.ditpertais.net. Diakses pada 1 Juni 2010. 